\section{Combining Preemergence Herbicides in Tank Mixtures or as Sequential Applications Provides Season-long Crabgrass Control in the Upper Midwest}

\author{
Christopher A. Proctor and Matt D. Sousek \\ Department of Agronomy and Horticulture, University of Nebraska-Lincoln, \\ 161 Keim Hall, Lincoln, NE 68583
}

\author{
Aaron J. Patton and Daniel V. Weisenberger \\ Department of Agronomy, Purdue University, 915 W. State Street, West Lafayette, \\ IN 47907-2054
}

\section{Zachary J. Reicher ${ }^{1}$ \\ Department of Agronomy and Horticulture, University of Nebraska-Lincoln, 161 Keim Hall, Lincoln, NE 68583} Additional index words. split application, annual grass, grassy weed, dithiopyr, pendimethalin,
prodiamine

\begin{abstract}
Preemergence (PRE) herbicides are used to control crabgrass (Digitaria spp.). Single spring applications are common in areas with relatively low crabgrass pressure, whereas sequential applications often are used to extend control in locations with high crabgrass pressure. Our objectives were to determine if changing a.i. in initial and sequential applications affects crabgrass control and if single spring applications of tankmixed PRE herbicides provide season-long crabgrass control. Studies were conducted 2009, 2010, and 2011 in West Lafayette, IN, and 2011 in Wymore, NE. The PRE herbicides prodiamine, pendimethalin, and dithiopyr were tested using different application strategies. Sequential applications were applied mid-April and mid-June using all possible combinations of the three herbicides and untreated for the initial and sequential application. These herbicides also were applied mid-April as single full-rate PRE application or as a tank mixture of two PRE herbicides at half-plus-half or half-plus-quarter rate. Season-long crabgrass control was consistently achieved using sequential applications regardless which of the three herbicides was used for initial or sequential applications. Single applications of tank mixtures also provided consistent crabgrass control, equivalent to single full-rate applications of the individual PRE herbicides. Tank mixtures of half-plusquarter rate and single half-rate applications resulted in more crabgrass cover than single full-rate or half-plus-half rate applications regardless of the herbicide applied.
\end{abstract}

Crabgrass (Digitaria spp.) is an annual grassy weed native to the lower 48 United States (U.S. Department of Agriculture, Natural Resources Conservation Service, 2011) and problematic in turf throughout the upper Midwest. Prodiamine [2,4-dinitro- $\mathrm{N}^{3}, \mathrm{~N}^{3}$-dipropyl-6(trifluoromethyl)-1,3-benzenediamine], pendimethalin [N-(1-ethylpropyl)-3,4-dimethyl-2, 6-dinitrobenzenamine], and dithiopyr [S, S' dimethyl 2-(difluoromethyl)-4-(2-methylpropyl)6-(trifluoromethyl)-3,5-pyridinedicarbothioate] are among the most common herbicides used for crabgrass control in turfgrass. Preemergence (PRE) herbicides have been applied as a single application in either the spring or the fall (Bhowmik and Bingham, 1990;

Received for publication 9 Mar. 2012. Accepted for publication 17 May 2012.

${ }^{1}$ To whom reprint requests should be addressed; e-mail zreicher2@unl.edu.
Dernoeden, 1993; Engle et al., 1975; Johnson, 1979; Reicher and Throssell, 1993; Reicher et al., 2011). However, single applications can provide inconsistent levels of crabgrass control, which is likely the result of environmental effects on turf density or herbicide dissipation; influenced by soil water and oxygen content or by organic matter content; volatilization; and microbial and photodegradation (Schleicher et al., 1995; Stahnke et al., 1991; Weber, 1990).

Sequential herbicide applications often are used to improve consistency of crabgrass control over single applications (Dernoeden, 1984; Johnson, 1977, 1996, 1997; Lockhart and Howatt, 2004; Parochetti et al., 1972). To the best of our knowledge, first mention of sequential application of PRE herbicides for annual grassy weed control in turfgrass was 1976 for goosegrass [Eleusine indica (L.) Gaertn.] and 1979 for crabgrass (Hall, 1976; Watschke et al., 1979). Reicher et al. (1991) found crabgrass control was most consistent when the same a.i. was used for both initial and sequential PRE applications. However, there was evidence at some of their test sites suggesting adequate control resulted if different a.i.s were used for initial and sequential applications (Reicher et al., 1991). Lawn care operators often use sequential applications of PRE herbicides in their multipleround application programs, and increased flexibility from using a different a.i. for initial and sequential applications could be more practical and/or economical than using the same a.i. for both applications. Furthermore, tank mixtures of PRE herbicides could expand the spectrum of weeds controlled as well as being more economical than using a single a.i. For instance, including dithiopyr in a spring application after crabgrass has begun to germinate will improve postemergence (POST) control of crabgrass over that expected from pendimethalin or prodiamine alone because dithiopyr has some POST activity on crabgrass up to the three- to four-leaf stage (Enache and Ilnicki, 1991). Tank mixtures typically include PRE and POST herbicides (Johnson, 1997; McCurdy et al., 2008; Parochetti et al., 1972). We found no mention of tank mixtures with only PRE herbicides; however, granular mixtures of bensulide $\{[\mathrm{S}-(\mathrm{O}, \mathrm{O}-$ diisopropyl phosphorodithioate)ester of $\mathrm{N}$-(2-mercaptoethyl)

Table 1. Preemergence herbicide treatments applied in initial and sequential applications in West Lafayette, IN, in 2009, 2010, 2011, and Wymore, NE, in 2011.

\begin{tabular}{lclc}
\hline Initial application & $\mathrm{kg}$ a.i./ha & Sequential application & $\mathrm{kg}$ a.i./ha \\
\hline Prodiamine & 0.42 & Prodiamine & 0.42 \\
Prodiamine & 0.42 & Pendimethalin & 1.68 \\
Prodiamine & 0.42 & Dithiopyr & 0.28 \\
Prodiamine & 0.42 & Untreated & - \\
Pendimethalin & 1.68 & Prodiamine & 0.42 \\
Pendimethalin & 1.68 & Pendimethalin & 1.68 \\
Pendimethalin & 1.68 & Dithiopyr & 0.28 \\
Pendimethalin & 1.68 & Untreated & - \\
Dithiopyr & 0.28 & Prodiamine & 0.42 \\
Dithiopyr & 0.28 & Pendimethalin & 1.68 \\
Dithiopyr & 0.28 & Dithiopyr & 0.28 \\
Dithiopyr & 0.28 & Untreated & - \\
Untreated & - & Prodiamine & 0.42 \\
Untreated & - & Pendimethalin & 1.68 \\
Untreated & - & Dithiopyr & 0.28 \\
Untreated & - & Untreated &
\end{tabular}


benzenesulfonamide]\} plus oxadiazon [2tert-butyl-4-(2,4-dichloro-5-isopropoxyphenyl)1,3,4-oxadiazolin-5-one] or oxadiazon plus prodiamine were effective in controlling crabgrass and goosegrass (Dernoeden et al., 1984; Hinton et al., 2001) and are commercially available. The objectives of our study were to determine if changing a.i. in initial and sequential applications affects seasonlong crabgrass control and if single spring applications of PRE tank mixtures provide season-long crabgrass control in the upper Midwest.

\section{Materials and Methods}

Studies were conducted for three years at Purdue University's W.H. Daniel Turfgrass Research and Diagnostic Center in West Lafayette, IN, and 1 year at Wymore Country Club in Wymore, NE. The crabgrass area in Indiana was a $10+$-year-old kentucky bluegrass (Poa pratensis L.) blend with a history of smooth crabgrass [Digitaria ischaemum (Schreb.) Schreb. ex Muhl.] pressure. Turf was maintained at a mowing height of $3.8 \mathrm{~cm}$ in 2009 and 2010 and $5.0 \mathrm{~cm}$ in 2011 and irrigated to prevent drought stress. Soil was a Chalmers silt loam (fine silty mixed mesic Typic Haplaquoll) with pH 7.2 and 3.8\% organic matter. No fertilizer was applied during the experiment, but $48 \mathrm{~kg}$ nitrogen/ha was applied in the fall before each experiment with urea $(46 \mathrm{~N}-0 \mathrm{P}-0 \mathrm{~K})$. The Nebraska location was a 40 -year-old stand of tall fescue (Festuca arundinacea Schreb.) and kentucky bluegrass naturally infested with large crabgrass [Digitaria sanguinalis (L.) Scop.]. The site was maintained at $5-\mathrm{cm}$ height-of-cut with no fertilizer applied during the study and irrigated to prevent drought injury. Soil was a Wymore silty clay loam (fine, smectitic, mesic Aquertic Argiudolls) with pH 6.6 and $8.1 \%$ organic matter. Herbicides were applied at both locations to plots measuring $1.5 \times 1.5 \mathrm{~m}$ using a $\mathrm{CO}_{2}$ pressurized sprayer with three flat fan nozzles (XR8002VS or LF8002; TeeJet Spraying Systems, Wheaton, IL) at $817 \mathrm{~L} \cdot \mathrm{ha}^{-1}$ and $207 \mathrm{kPA}$. Percent crabgrass cover was visually estimated 15 June $\pm 7 \mathrm{~d}$ and 15 Aug. \pm 10 d. The experimental design was a randomized complete block with three replications. Our study was conducted at multiple locations and over multiple years. Locationby-years were combined as environments to simplify our analysis, which is a common practice among researchers (Piepho, 1998). A mixed linear model was used to describe the data with herbicide treatment as a fixed factor, environment as a random factor, and it was assumed no herbicide-by-environment interaction existed. Most uses of mixed models assume homogeneity of variance; however, best linear unbiased prediction, used in mixed linear models for estimation of random effects, is able to accommodate heterogeneous variances (Gianola, 1986). Variance for some factors such as environment tends to be heterogeneous. Estimation and testing procedures for heterogeneous variance are commonly used in both crop and animal breeding (Foulley and Quaas, 1995; Piepho, 1998) and can be performed with PROC MIXED or PROC GLIMMIX in SAS (SAS Institute, 2009). Variance components were estimated using Restricted Maximum Likelihood (Patterson

and Thompson, 1971; Thompson, 1962). As a result of heterogeneous variance between environments in our study, the variance for each environment was modeled separately with PROC GLIMMIX (Littell et al.,

Table 2. Crabgrass control treatments for preemergence herbicides applied as single April applications in West Lafayette, IN, in 2010, 2011, and Wymore, NE, in 2011.

\begin{tabular}{lc}
\hline Treatment & Rate of application (kg a.i./ha) \\
\hline Prodiamine FR & 0.84 \\
Prodiamine HR & 0.43 \\
Prodiamine HR + pendimethalin HR & $0.43+1.68$ \\
Prodiamine HR + pendimethalin QR & $0.43+0.84$ \\
Prodiamine HR + dithiopyr HR & $0.43+0.28$ \\
Prodiamine HR + dithiopyr QR & $0.43+0.14$ \\
Pendimethalin FR & 3.36 \\
Pendimethalin HR & 1.68 \\
Pendimethalin HR + prodiamine QR & $1.68+0.21$ \\
Pendimethalin HR + dithiopyr HR & $1.68+0.28$ \\
Pendimethalin HR + dithiopyr QR & $1.68+0.14$ \\
Dithiopyr FR & 0.56 \\
Dithiopyr HR & 0.28 \\
Dithiopyr HR + prodiamine QR & $0.28+0.21$ \\
Dithiopyr HR + pendimethalin QR & $0.28+0.84$ \\
Untreated & \\
\hline
\end{tabular}

Untreated

${ }^{\mathrm{z}} \mathrm{FR}=$ full rate.

${ }^{\mathrm{y}} \mathrm{HR}=$ one-half rate.

${ }^{\mathrm{x}} \mathrm{QR}=$ one-quarter rate.

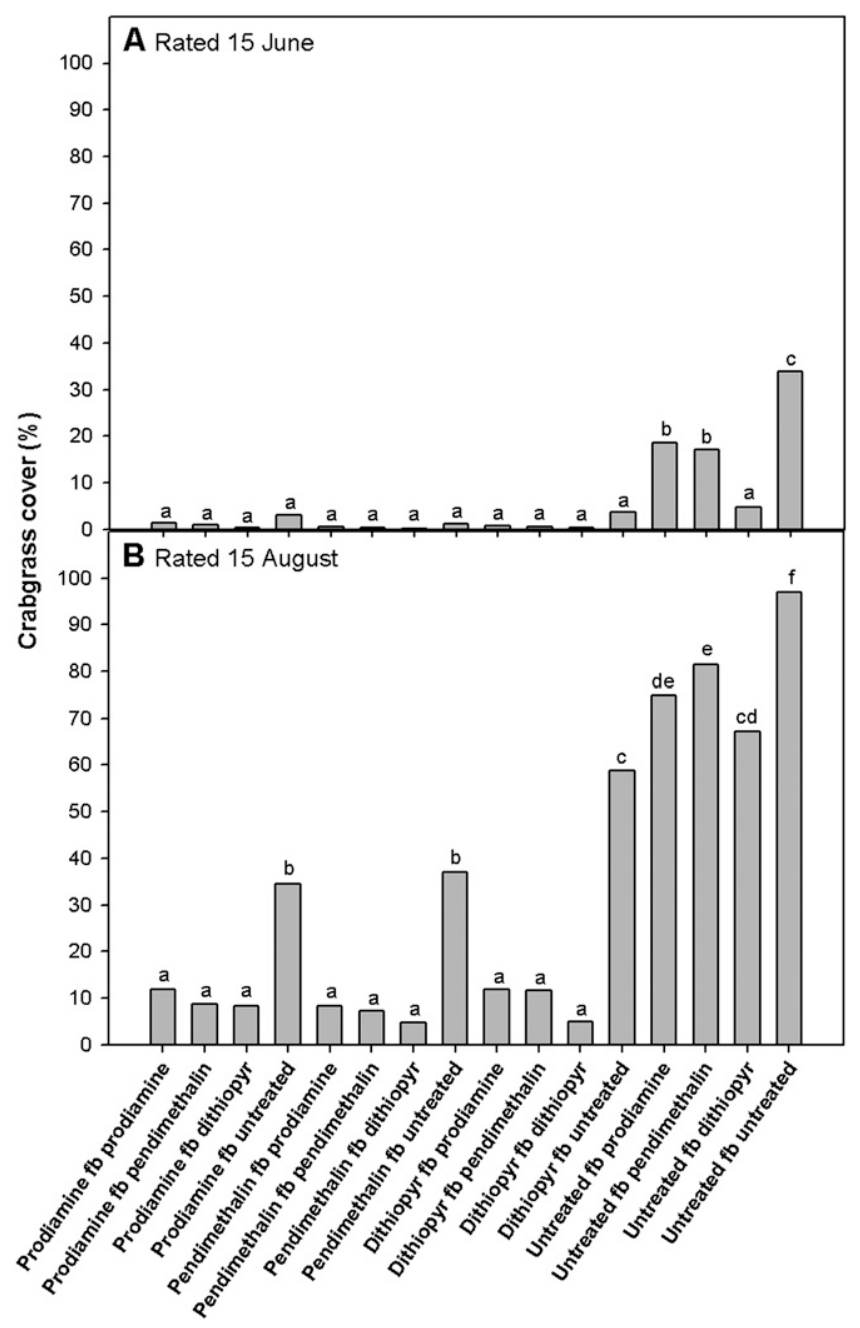

Fig. 1. Percent crabgrass cover on 15 June (A) and 15 Aug. (B) averaged over four environments for initial preemergence herbicide applications followed by $(\mathrm{fb})$ sequential applications on $15 \mathrm{Apr}$. and 1 June. Bars with the same letter within each rating are not significantly different $(P \leq 0.05)$. 
2006). Mean separation was conducted with LSMEANS, and comparisons were made at $\alpha=0.05$. Preplanned treatment contrasts between single and sequential PRE applications were made using ESTIMATE in PROC GLIMMIX.

Sequential applications (Objective 1). This experiment was performed in Indiana in 2009, 2010, and 2011 and in Nebraska in 2011. Initial herbicide applications were applied 15 Apr. $\pm 6 \mathrm{~d}$ with sequential applications on 1 June $\pm 1 \mathrm{~d}$. Treatments were a $4 \times 4$ factorial with all possible combinations of untreated, prodiamine $4 \mathrm{FL}$ at $0.42 \mathrm{~kg}$ a.i./ha, pendimethalin $3.8 \mathrm{AQ}$ at $1.68 \mathrm{~kg}$ a.i./ha, or dithiopyr $2 \mathrm{EW}$ at $0.28 \mathrm{~kg}$ a.i./ha as the initial or sequential application (Table 1). Within $24 \mathrm{~h}$ of application, herbicides were watered-in by natural precipitation or irrigation with $\geq 2.5 \mathrm{~mm}$ water.

Tank mixtures (Objective 2). This experiment was conducted in Indiana in 2010 and 2011 and in Nebraska in 2011. Treatments were applied 15 Apr. $\pm 6 \mathrm{~d}$ as a single application using prodiamine $4 \mathrm{FL}$ at $0.84 \mathrm{~kg}$ a.i./ha, pendimethalin $3.8 \mathrm{AQ}$ at $3.36 \mathrm{~kg}$ a.i./ha, or dithiopyr $2 \mathrm{EW}$ at $0.56 \mathrm{~kg}$ a.i./ha. Each herbicide was applied alone at the full rate (FR), at the one-half rate (HR), and in a mixture with the HR of each herbicide combined with either the HR or one-quarter rate (QR) of one of the other two herbicides (Table 2). Herbicides were watered in using the same method described previously.

\section{Results and Discussion}

Sequential applications. Crabgrass cover data recorded on both 15 June and 15 Aug. revealed a significant interaction between initial and sequential applications, which was entirely the result of treatments that were untreated in the initial or sequential application. Excluding treatments with untreated, there was no difference in crabgrass cover as a result of the PRE treatments in June regardless of the herbicide used in either initial or sequential applications (Fig. 1A). Untreated followed by (fb) dithiopyr provided June crabgrass cover similar to any treatment including an herbicide in the initial and sequential application and $15 \%$ less crabgrass cover than the untreated $\mathrm{fb}$ pendimethalin or untreated fb prodiamine. This was the result of dithiopyr's POST activity on young crabgrass (Enache and Ilnicki, 1991; Reicher et al., 1999). Excluding treatments with the untreated in initial or sequential applications, there were no differences in August crabgrass cover ratings regardless of herbicide used in either initial or sequential applications (Fig. 1B). Crabgrass cover was less than $12 \%$, regardless of herbicide used for initial or sequential applications compared with $95 \%$ crabgrass cover in the untreated $\mathrm{fb}$ untreated. Treatments that were untreated in initial or sequential applications resulted in $35 \%$ to $82 \%$ crabgrass cover by August (Fig. 1B).

Extension specialists commonly recommend sequential PRE applications over a single PRE application for more consistent crabgrass control in difficult-to-manage areas. This is despite relatively few refereed reports on this strategy (Dernoeden, 1984; Johnson, 1996). For the current study, contrasts were performed comparing all sequential applications with herbicide applied in the initial and sequential application to all single FR applications, which showed twice as much crabgrass cover in August from single FR applications ( $21 \%$ crabgrass cover) than sequential applications ( $9 \%$ crabgrass cover) (data not shown). These results help improve confidence in recommending sequential applications over single applications for improved crabgrass control. Dernoeden (1984) also reported reduced crabgrass coverage with a sequential application strategy compared with a full rate applied PRE when applied over multiple years at reduced rates.

We found little published research on PRE crabgrass control when different a.i.s were used for initial and sequential applications. Reicher et al. (1991) used a single low rate of pendimethalin $\left(1.12 \mathrm{~kg} \cdot \mathrm{ha}^{-1}\right)$ as the initial application followed by sequential applications of eight current or older herbicides. The lower initial rate of pendimethalin used in that study may have dissipated by the time sequential applications were made, thus resulting in reduced control from most of the sequential applications. Their 1991 data show no difference in crabgrass control through August with pendimethalin fb either pendimethalin, prodiamine, or dithopyr at three of four sites tested. Although previous recommendations have been to apply the same a.i. for initial and sequential applications, results from our study suggest currently available a.i.s could be interchanged between initial and sequential application. Similar to our results, research reports from North Carolina State University found no difference in smooth crabgrass or goosegrass cover rated in August when dithiopyr was applied in March fb dithiopyr, pendimethalin, or prodiamine in May (Warren, 2003; Warren and Yelverton, 2003).

Tank mixtures. Crabgrass cover in June was less than $7 \%$ in plots of all tank mixture treatments compared with $35 \%$ in untreated plots, and no differences occurred in crabgrass control between single FR and tank mixture applications (data not shown). In August, there was 94\% crabgrass cover in untreated plots, which was significantly more than all other treatments (Fig. 2). There was no difference in crabgrass cover in August in plots treated with prodiamine FR, pendimethalin FR, or dithiopyr FR and all combinations of the three herbicides in tank mixtures of HR-plus-HR. All tank mixtures with HRplus-QR resulted in more crabgrass cover than the HR-plus-HR tank mixtures. All three herbicides applied as a single a.i. HR resulted in more crabgrass cover in August than any of the single a.i. FR, HR-plus-HR tank-mixtures, or HR-plus-QR tank mixtures. The HR or HR-plus-QR tank mixtures of PRE herbicides were less effective than the HR-plusHR tank mixtures (Fig. 2). However, our applications were to sites where crabgrass was not controlled the year prior with a PRE herbicide. Others (Dernoeden, 2001; Watschke and Borger, 1995) have shown that reduced rate applications of PRE herbicides can successfully control crabgrass when applied to a location receiving a full rate PRE herbicide the year prior. Most published research with tank-mixed herbicides for controlling crabgrass are combinations of PRE and POST

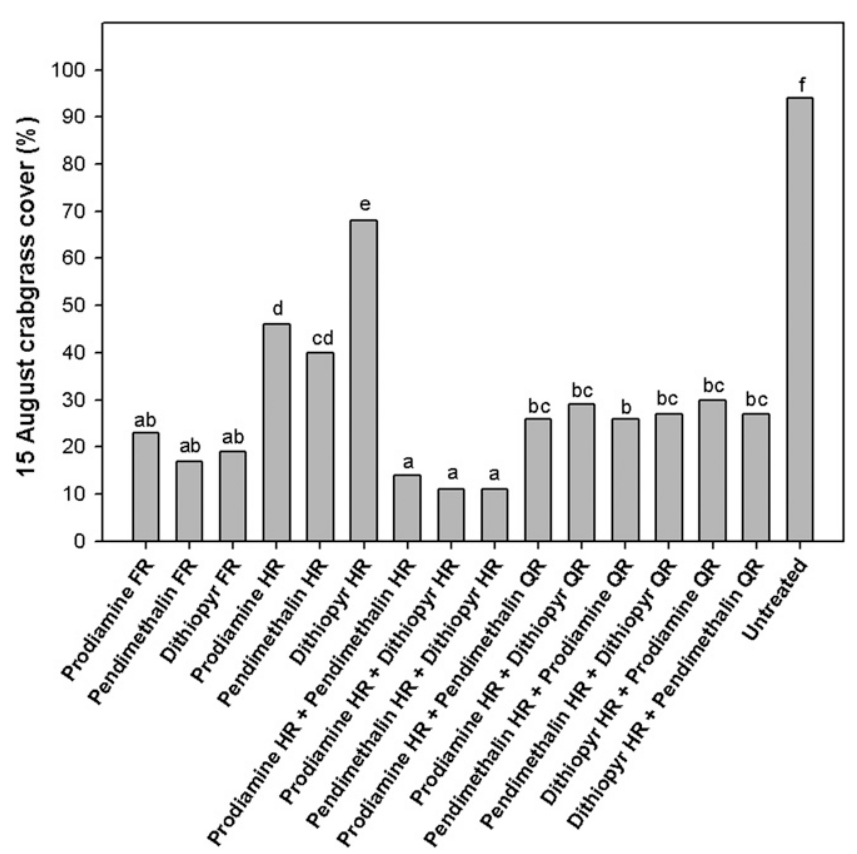

Fig. 2. Percent crabgrass cover on 15 Aug. averaged over three environments after a single April application of prodiamine, pendimethalin, or dithiopyr alone or tank-mixed with prodiamine, pendimethalin, or dithiopyr. Bars with the same letter not significantly different $(P \leq 0.05) . \mathrm{FR}=$ full rate; $\mathrm{HR}=$ one-half rate; $\mathrm{QR}=$ one-quarter rate. 
herbicides (Johnson, 1994; McCurdy et al., 2008). Tank mixtures often are used to increase the spectrum of weeds controlled as well as allow more flexibility in the timing of application. To effectively control both crabgrass and goosesgrass, PRE granular mixtures of bensulide plus oxadiazon or pendimethalin plus oxidiazon have been used effectively (Dernoeden et al., 1984; Hinton et al., 2001; Warren, 2003).

In our study, season-long crabgrass control was consistently achieved using sequential applications of prodiamine, pendimethalin, or dithiopyr regardless of herbicides used for the initial and sequential application. Tank mixes using HR-plus-HR of prodiamine, pendimethalin, or dithiopyr also provided similar and consistent levels of crabgrass control compared with the FR single a.i. applications of these herbicides. Turfgrass professionals will benefit from being able to use different a.i.s for sequential and/or tank mixture applications of PRE herbicides. For example, lawn care operators making initial PRE applications as crabgrass is starting to germinate could tank-mix dithiopyr with prodiamine or pendimathalin for both PRE and early POST control. Similarly, using dithiopyr for sequential applications, regardless of the herbicide used in initial applications, will provide POST control up to the three- to four-leaf stage in areas where crabgrass is already germinating or on lawns that did not receive an initial application. This flexibility could allow professionals to exhaust herbicide supplies remaining from previous years and/or take advantage of differential costs of herbicides.

\section{Literature Cited}

Bhowmik, P.C. and S.W. Bingham. 1990. Preemergence activity of dinitroaniline herbicides used for weed control in cool-season turfgrasses. Weed Technol. 4:387-393.

Dernoeden, P.H. 1984. Management of preemergence herbicides for crabgrass control in transitionzone turf. HortScience 19:443-445.

Dernoeden, P.H. 1993. November applied preemergence herbicides for smooth crabgrass control the following summer. Intl. Turfgrass Soc. Res. J. 7:291-297.

Dernoeden, P.H. 2001. Reduced herbicide rates for smooth crabgrass control in the mid-Atlantic region. Intl. Turfgrass Soc. Res. J. 9:10051008.

Dernoeden, P.H., T.L. Watschke, and J.K. Mathias. 1984. Goosegrass (Eleusine indica) control in turf in the transition zone. Weed Sci. 32:4-7.
Enache, A.J. and R.D. Ilnicki. 1991. BAS 514 and dithiopyr for weed control in cool-season turfgrasses. Weed Technol. 5:616-621.

Engle, R.E., C.W. Bussey, and P. Catron. 1975. Crabgrass and goosegrass control in turfgrass with several preemergence herbicides. Proc. Northeast. Weed Sci. Soc. 29:369-374.

Foulley, J.L. and R.L. Quaas. 1995. Heterogeneous variances in Gaussian linear mixed models. Genet. Sel. Evol. 27:211-228.

Gianola, D. 1986. On selection criteria and estimation of parameters with the variance is heterogeneous. Theor. Appl. Genet. 72:671-677.

Hall, J.R. 1976. Control of goosegrass in coolseason turf with split applications of preemergence herbicides. Proc. Northeast. Weed Sci. Soc. 30:357.

Hinton, J., T. Gannon, and F. Yelverton. 2001. Comparison of standard preemergence crabgrass herbicide (01-T14). North Carolina State University. 2001 Turfgrass Pasture Weed Control and PGR Annual Report. p. 1-4.

Johnson, B.J. 1977. Sequential herbicide treatments for large crabgrass and goosegrass control in bermudagrass. Agron. J. 69:1012-1014.

Johnson, B.J. 1979. Large crabgrass control in turfgrasses with fall-applied herbicides. Agron. J. 71:137-138.

Johnson, B.J. 1994. Tank-mixed herbicide on large crabgrass (Digitaria sanguinalis) and goosegrass (Eleusine indica) control in common bermudagrass (Cynodon dactylon) turf. Weed Sci. 42:216-221.

Johnson, B.J. 1996. Effect of reduced dithiopyr and prodiamine rates on large crabgrass (Digitaria sanguinalis) control in common bermudagrass (Cynodon dactylon) and tall fescue (Festuca arundinacea) turf. Weed Technol. 10:322-326.

Johnson, B.J. 1997. Sequential applications of preemergence and postemergence herbicides for large crabgrass (Digitaria sanguinalis) control in tall fescue (Festuca arundinacea) turf. Weed Technol. 11:693-697.

Littell, R., G. Milliken, W. Stroup, R. Wolfinger, and O. Schabenberger. 2006. SAS for mixed models. 2nd Ed. SAS Institute Inc., Cary, NC.

Lockhart, S.J. and K.A. Howatt. 2004. Split applications of herbicides at reduced rates can effectively control wild oat (Avena fatua) in wheat. Weed Technol. 18:369-374.

McCurdy, J.D., J.S. McElroy, G.K. Breeden, and D.A. Kopsell. 2008. Mesotrione plus prodiamine for smooth crabgrass (Digitaria ischaemum) control in established bermudagrass turf. Weed Technol. 22:275-279.

Parochetti, J.V., R.W. Feeny, and S.R. Colby. 1972. Preemergence herbicides plus postemergence chloroxuron on soybeans. Weed Sci. 20:548-553.

Patterson, H.D. and R. Thompson. 1971. Recovery of inter-block information when blocks sizes are unequal. Biometrika 58:545-554.
Piepho, H.P. 1998. Methods for comparing the yield stability of cropping systems- a review. J. Agron. Crop Sci. 180:193-213.

Reicher, Z.J. and C.S. Throssell. 1993. Efficacy of fall and spring-applied preemergence herbicides for annual grass control in kentucky bluegrass. Intl. Turfgrass. Soc. Res. J. 7:273276.

Reicher, Z.J., C.S. Throssell, and J.L. Lefton. 1991. Annual grass control in cool season turf with sequential applications of unlike preemergence herbicides. Weed Technol. 5:387-391.

Reicher, Z.J., D.V. Weisenberger, M.W. Melichar, D.L. Loughner, J.A. Borger, and M.B. Naedel. 2011. Late fall and early spring application of granular preemergence herbicide on a fertilizer carrier for season-long crabgrass control. J. Environ. Hort. 29:65-70.

Reicher, Z.J., D.V. Weisenberger, and C.S. Throssell. 1999. Turf safety and effectiveness of dithiopyr and quinclorac for large crabgrass (Digitaria sanguinalis) control in spring-seeded turf. Weed Technol. 13:253-256.

SAS Institute. 2009. SAS users guide. Version 9.2. 2nd Ed. SAS Inst., Cary, NC.

Schleicher, L.C., P.J. Shea, R.N. Stougaard, and D.R. Tupy. 1995. Efficacy and dissipation of dithiopyr and pendimethalin in perennial ryegrass (Lolium perenne). Turf. Weed Sci. 43:140148.

Stahnke, G.K., P.J. Shea, D.R. Tupy, and R.N. Stougaard. 1991. Pendimethalin dissipation in Kentucky bluegrass turf. Weed Sci. 39:97-103.

Thompson, W.A. 1962. The problem of negative estimates of variance components. Ann. Math. Stat. 33:273-289.

U.S. Department of Agriculture, Natural Resources Conservation Service. 2011. The PLANTS database. National Plant Data Team, Greensboro, NC. 12 Dec. 2011. <http://plants.usda. gov>.

Warren, L.S. 2003. Efficacy of single vs. split applications for PRE smooth crabgrass control in tall fescue (03-T9). North Carolina State University. 2003 Herbicide-PGR Reports. p. 1-5.

Warren, L.S. and F. Yelverton. 2003. Split applications of dimension and dinitroaniline herbicides for PRE smooth crabgrass control in tall fescue (03-T8). North Carolina State University. 2003 Herbicide-PGR Reports. p. 1-5.

Watschke, T.L. and J.A. Borger. 1995. Controlling crabgrass using lower rates or fall applications. Proc. Northeastern Weed Sci. Soc. 49:73-74 (Abstr.).

Watschke, T.L., J.M. Duich, and M.S. Welterlen. 1979. Crabgrass control with single and split applications of preemergence herbicides. Proc. Northeast. Weed Sci. Soc. 33:270-273.

Weber, B.J. 1990. Behavior of dinitroaniline herbicides in soils. Weed Technol. 4:394406. 